\title{
ZNAČAJ UVRŠTAVANJA ČASOPISA \\ U BAZE PODATAKA WOSCC I SCOPUS ZA POVEĆANJE VIDLJIVOSTI UNUTAR AKADEMSKE ZAJEDNICE NA PRIMJERU ČASOPISA MATHEMATICAL COMMUNICATIONS
}

\author{
THE SIGNIFICANCE OF INCLUDING JOURNALS \\ IN WOSCC AND SCOPUS DATABASES TO INCREASE \\ THE JOURNALS' VISIBILITY INSIDE THE ACADEMIC \\ COMMUNITY ON THE EXAMPLE OF THE MATHEMATICAL \\ COMMUNICATIONS JOURNAL
}

\author{
Mirna Šušak Lukačević \\ Odjel za matematiku \\ Sveučilište Josipa Jurja Strossmayera u Osijeku \\ msusak@mathos.hr \\ Sanda Hasenay \\ Prehrambeno-tehnološki fakultet Osijek \\ Sveučilište Josipa Jurja Strossmayera u Osijeku \\ hasenays@ptfos.hr \\ Svjetlana Mokriš \\ Gradska i sveučilišna knjižnica Osijek \\ marendic@gskos.hr
}

UDK / UDC 050:001

Stručni rad / Professional paper

Prihvaćeno / Accepted: 3. 5. 2017.

\section{Sažetak}

U radu je prema bibliometrijskim pokazateljima analiziran časopis Mathematical Communications u razdoblju od 1996. do 2015. godine. U razdoblju od dvadeset godi-

Vjesnik bibliotekara Hrvatske 60, 2-3(2017), 221-240

ISSN 0507-1925

(C) VBH 2017. 
na, od prvog do dvadesetog godišta 2015. godine, uzorak čine 582 rada. Cilj istraživanja bio je utvrditi je li vidljivost časopisa porasla otkako je časopis indeksiran u bazama podataka Web of Science Core Collection (WoSCC) i Scopus. Rezultati istraživanja pokazali su da je, nakon što je časopis indeksiran u bazama podataka WoSCC i Scopus, broj radova u pojedinom godištu, a sukladno tomu i broj stranica, značajno porastao, da se u njemu gotovo isključivo objavljuju izvorni znanstveni radovi, da je broj inozemnih autora povećan, da je povećan broj referenci na koje autori upućuju, a koji se u značajnom broju odnose na strane časopise i knjige te da broj referenci koje se odnose na radove objavljene u časopisu MC nije velik. Osim toga, značajno je porasla citiranost radova u bazama WoSCC i Scopus, a primjećuju se i pozitivni pomaci pri rangiranju časopisa u izvješćima o citiranosti časopisa JCR (Journal Citation Report) i SCImago Journal \& Country Rank.

Sustavnim radom i uređivačkom politikom u publiciranju radova uredničkoga odbora $\mathrm{MC}$ je postao prepoznatljiv i prihvaćen časopis u području matematike.

Ključne riječi: časopis Mathematical Communications, bibliometrijski pokazatelji, indeksiranost, citiranost

\section{Summary}

The paper, using the bibliometric indicators, analyzes the journal Mathematical Communications (MC) in the period from 1996 to 2015. The researched period of 20 years includes 20 volumes (volumes 1 to 20) and the sample of 582 articles. The goal of the study was to research whether the journal's visibility has increased after it has been indexed in Web of Science Core Collection (WoSCC) and Scopus databases. The results have shown that after the journal has been indexed in WoSCC and Scopus databases, the number of articles in a single volume, and proportionally, the number of pages have increased significantly. Also, the journal has started to publish exclusively scientific articles, the number of foreign authors has increased, and the number of references used by the article authors, mostly referring to foreign journals and books, has also increased. However, the research has shown that the number of references to the articles published in the MC is not very large. Finally, the research has shown that there is a significant increase in the number of citations in WoSCC and Scopus databases and some positive trends are noted regarding the journal ranking according to JRC (Journal Citations Report) and SCImago Journal \& Country Rank.

To conclude, due to the systematic effort and the article publishing policy of the Editorial board, the $\mathrm{MC}$ has become a recognizable and well accepted journal in the field of mathematics.

Keywords: Mathematical Communications journal, bibliometric indicators, indexing, citation 


\section{Uvod}

Kako bi znanstvenici imali uvid u rad svojih kolega, odnosno kako bi što lakše komunicirali, tj. podijelili rezultate svojih istraživanja, još 1665 . godine pokrenuti su prvi znanstveni časopisi (Journal des sçavans u Parizu, Philosophical transactions u Londonu) i do danas su ostali jedno od najvažnijih sredstava znanstvenog priopćavanja. ${ }^{1}$ Osim toga, jedna od važnih uloga časopisa jest i arhiviranje znanstvenih postignuća, a uz časopise je vezano i uspostavljanje recenzije kao sustava prethodnog vrednovanja napisanog, odnosno kontrola kvalitete napisanog i intelektualno vlasništvo kao pravo na otkriće te kao najsnažniji izvor motivacije u znanstvenom radu. ${ }^{2}$

Znanstvena komunikacija nadgradnja je znanstvenoga izdavaštva, a uključuje formalne i neformalne mreže koje koriste znanstvenici kako bi razvijali ideje, razmjenjivali informacije (uključujući podatke), vrednovali tuđa istraživanja, objavljivali rezultate, dijelili svoje pronalaske i čuvali sve to za nove naraštaje. ${ }^{3}$ Znanstvenici kroz časopis mogu biti u različitim ulogama: autori (znanstveni autoriteti kroz članke koje objavljuju), recenzenti (mehanizmi kontrole kvalitete u području kojim se bave), urednici (etičke norme, odgovornost i povjerenje znanstvene zajednice).

Nekomercijalnim znanstvenim časopisima smatraju se oni čiji se izdavači deklariraju kao neprofitni, a najčešće ih izdaju strukovna društva, udruge, visokoškolske ustanove ili neprofitne izdavačke kuće. ${ }^{4}$

Časopis Mathematical Communications (MC) pokrenuli su 1996. godine znanstvenici sa Zavoda za primijenjenu matematiku okupljeni oko Udruge matematičara Osijek i redovito izlazi dva puta godišnje. Iznimka je bilo godište 19 (2014. godina) kada se uredništvo odlučilo na objavljivanje triju sveščića. MC danas izdaje Odjel za matematiku Sveučilišta u Osijeku u suradnji s Udrugom matematičara Osijek. Urednički odbor čine znanstvenici iz Republike Hrvatske i svijeta. ${ }^{5}$ MC je do sada imao dva glavna urednika. Prof. dr. sc. Rudolf Scitovski

\footnotetext{
1 Hrvatska enciklopedija - časopis [citirano: 2016-07-14]. Dostupno na http://www.enciklopedija.hr/Natuknica.aspx?ID=13196.

2 Šercar, Tvrtko. Časopis kao sredstvo institucionalizacije znanosti. // Acta stomatologica Croatica 21, 4(1987), str. 320.

3 Keener, Molly; Joy Kirchner; Sarah Shreeves; Lee Van Orsdel. 10 things you should know about scholarly communication. // ACRL 14th National Conference 2009 "Scholarly Communication 101" workshop; last updated May 10, 2013. Str. 1. [citirano: 2017-04-25] Dostupno na http://www.ala.org/acrl/sites/ala.org.acrl/files/content/issues/scholcomm/docs/ten_things_you_ should_know.pdf.

4 Macan, Bojan; Jadranka Stojanovski. Analiza novčane potpore Ministarstva znanosti, obrazovanja i športa hrvatskim znanstvenim časopisima. // Kemija u industriji 57, 3(2008), str. 115.

5 Urednički odbor može se vidjeti na web-stranici: http://www.mathos.unios.hr/mc/index.php/ mc/about/editorialTeam.
} 
bio je glavni urednik od 1996. do 2012., a od 2013. glavni je urednik prof. dr. sc. Dragan Jukić. Oni su i najzaslužniji, kako za osnivanje samoga časopisa tako i za njegovu kvalitetu te kontinuitet izlaženja. Recenzije su međunarodne (najmanje dvije), a kontakti s autorima i recenzentima obavljaju se putem interneta. Izlaženje časopisa sufinancira Ministarstvo znanosti, obrazovanja i sporta Republike Hrvatske od 1998. godine. MC je jedini znanstveni časopis iz područja prirodnih znanosti čiji je izdavač jedna od sastavnica Sveučilišta Josipa Jurja Strossmayera u Osijeku. U časopisu se objavljuju originalni znanstveni i pozvani pregledni radovi iz područja čiste i primijenjene matematike. Osim kategoriziranih radova, časopis donosi i priloge koji su vezani uz važna događanja na Odjelu za matematiku i u Udruzi matematičara te informacije vezane uz Matematički kolokvij u Osijeku. Od 2013. godine uredništvo MC-a odlučilo je da se publiciranje obavlja preko Open Journal Systema (OJS - an electronic journal management and publishing system).

S obzirom na to da se od prvih zamisli o pokretanju časopisa težilo njegovoj internacionalizaciji, jedna od važnih odluka bila je na kojem će se jeziku objavljivati radovi. Kao što navodi i M. Jokić, jezik na kojem je članak napisan gotovo je od presudne važnosti hoće li i u kojoj mjeri članak biti pročitan. ${ }^{6}$ Prema navodu 1. Bornmann et al., za publikacije na engleskom jeziku očekuje se veća citiranost nego za one objavljenje na drugim jezicima. Važnost časopisa, kako za Odjel za matematiku tako i za cijelo Sveučilište u Osijeku, ogleda se i u razmjeni časopisa MC s časopisima iz cijeloga svijeta. ${ }^{7}$

Polazeći od temeljne postavke da je znanje baština cijeloga čovječanstva, rađa se ideja da rezultati znanstvenih istraživanja trebaju biti dostupni svima. Zamisao se počinje konkretizirati pojavom prvih časopisa i knjiga sa slobodnim pristupom cjelovitom tekstu na internetu. ${ }^{8}$ E-oblik MC-a dostupan je na stranicama Odjela za matematiku', a od ožujka 2006. godine časopis je uključen i na Portal znanstvenih časopisa Republike Hrvatske HRČAK gdje se nalaze cjeloviti tekstovi radova svih godišta ${ }^{10} \mathrm{u}$ otvorenom pristupu (engl. open access), što je bila jedna od važnih odluka Uredništva časopisa za još veću vidljivost publiciranih radova. MC je indeksiran u međunarodnim bazama: Web of Science Core Collection (Science Citation Index Expanded), Current Mathematical Publications, MathSciNet

\footnotetext{
6 Jokić, Maja. Bibliometrijski aspekti vrednovanja znanstvenog rada. Zagreb: Sveučilišna knjižara, 2005. Str. 81.

7 Više o razmjeni može se pročitati u radu: Šušak Lukačević, Mirna ; Sanda Hasenay ; Ivana Šuvak-Pirić. Izgradnja zbirke periodike razmjenom za časopis Mathematical Communications u knjižnici Odjela za matematiku Sveučilišta u Osijeku. // Knjižničarstvo 17, 2(2013), 57-74.

8 Borić, Vesna; Mihovil Strujić. Bibliometrijska analiza Acta stomatologica Croatica za razdoblje od godine 1987. do 2006. // Acta stomatologica Croatica 40, 4(2006), str. 338.

9 Poveznica na web-stranicu nalazi se na adresi http://www.mathos.hr/mc.

10 Poveznica na Portal: http://hrcak.srce.hr/mathematical-communications.
} 
(Mathematical Review), Zentralblatt für Mathematik / Mathematics Abstracts, MATH on STN International, CompactMath, INSPEC, Current Index to Statistics, Urlich's, DOAJ, SCOPUS, EBSCO.

Važnost je bibliometrije u tome što se na taj način može vidjeti je li i koliko je neki rad čitan, pregledavan, odnosno pohranjivan, jer sve to mogu biti pokazatelji njegove kvalitete. Isto tako, važno je za što i kako koristiti pojedine bibliometrijske pokazatelje. Vrsta rada, broj suautora, broj referenci i broj stranica citirane publikacije trebaju biti uzeti u statističku analizu kao neovisne varijable. ${ }^{11}$ Citati služe kao pokazatelj odjeka pojedinoga rada u znanstvenoj zajednici, pokazatelj prihvaćenosti i odjeka pojedinoga časopisa u znanstvenoj zajednici. Čimbenik odjeka (IF) jedan od pokazatelja kvalitete časopisa, ali se ne smije koristiti za procjenu kvalitete pojedinačnoga rada objavljenog u časopisu ni znanstvenika koji je napisao taj rad. H-indeks pokazatelj je konstantnosti prihvaćenosti radova objavljenih u nekom časopisu, radova nekoga znanstvenika, ustanove i sl. u znanstvenoj zajednici i izračunava se na temelju citata. Ono što je važno napomenuti jest to da se uspoređivati po citatima, čimbeniku odjeka ili h-indeksu može isključivo unutar znanstvenoga područja. ${ }^{12}$ Primjena matematičkih i statističkih metoda bibliometrije, poput drugih disciplina koje rabe identične ili slične matematičke i statističke metode i tehnike, posjeduje znatno širi djelokrug i nadilazi isključivu primjenu $u$ analizi formalnih svojstava znanstvenih publikacija i sustava znanosti kad se on promatra kao informacijski proces. ${ }^{13} \mathrm{U}$ ovome radu procjena kvalitete časopisa $\mathrm{MC}$ vršit će se u skladu s podacima iskazanim u izvješćima o citiranosti časopisa JCR (Journal Citation Report) ${ }^{14}$ i SCImago Journal \& Country Rank.

\section{Cilj i metode istraživanja}

Cilj istraživanja bio je utvrditi je li vidljivost časopisa porasla otkako je časopis indeksiran u, trenutno za hrvatsku akademsku zajednicu najznačajnijim, bazama podataka Web of Science Core Collection i Scopus.

11 Bornmann, Lutz; Rüdiger Mutz; Christoph Neuhaus; Hans-Dieter Daniel. Citation counts for research evaluation: standards of good practice for analyzing bibliomteric data and presenting and interpreting results. // Ethics in Science and Enviromental Politcs 8(2008), str. 93.

12 Macan, Bojan. Kriteriji za evaluaciju znanstvenih časopisa - prednosti i mane. // 9. Seminar knjižnica u sustavu znanosti i visoke naobrazbe "Knjižnica uzvraća udarac: reorganizacija imperija”. Zagreb, 13. i 14. studenoga 2009. Slajd 34. [citirano: 2017-04-25] Dostupno na https://bib. irb.hr/datoteka/437794.Macan_B_Evaluacija_casopisa.pdf.

13 Pehar, Franjo. Od statističke bibliografije do bibliometrije: povijest razvoja kvantitativnog pristupa istraživanju pisane riječi. // Libellarium 3, 1(2010), str. 2.

14 JCR je statistička baza podataka na temelju citatnih podataka dobivenih iz citatnih indeksa SCI i SSCI o kojoj više možete pročitati na Portalu elektroničkih izvora za hrvatsku akademsku i znanstvenu zajednicu [citirano: 2017-04-25] Dostupno na http://baze.nsk.hr/baza/journal-citation-reports/. 
Analiza MC-a provela se uz pomoć tzv. pokazatelja publikacijske aktivnosti, na temelju jednostavnih brojanja (engl. publication count) bibliografskih entiteta i pridruženih im atributa, poput broja radova, autora, časopisa, ali isto tako i referencija, tj. citata. Premda je riječ o jednostavnim statističkim i matematičkim postupcima, ta vrsta mjerenja omogućuje opći uvid u publikacijsku aktivnost i produktivnost. ${ }^{15}$ Podaci koji su bili predmet istraživanja obrađeni su u programu Microsoft Excel te su prikazani tablično i grafički.

U radu je obrađeno 20 godišta, ukupno 41 sveščić časopisa. Parametri za istraživanje prikupljeni su iz časopisa te iz baza Web of Science Core Collection i Scopus.

\section{Rezultati i rasprava}

Uzorak za analizu činila su 582 rada objavljena u časopisu MC. Obuhvaćeni su izvorni znanstveni radovi, stručni radovi, pregledni radovi i jedan ispravak navedenih izvoda u radu od strane drugih autora. ${ }^{16}$ Prilozi i informacije nisu obuhvaćeni. Radovi su analizirani kroz sljedeće kategorije: broj objavljenih radova i broj stranica, vrste objavljenih radova, država i kontinent odakle dolaze autori, broj autora po jednom radu, broj i vrsta izvora zastupljenih referenci, radovi u kojima su kao reference navedeni drugi radovi zastupljeni u MC-u, broj indeksiranih i citiranih radova u bazama WoSCC i Scopus, citiranost neindeksiranih radova u bazama WoSCC i Scopus, IF, kvartil i poredak unutar kategorije u izvješćima o citiranosti časopisa JCR (Journal Citation Report) i SCImago Journal \& Country Rank.

\subsection{Radovi objavljeni u časopisu MC}

Analiza varijance broja stranica pokazala je da su 582 rada publicirana u MC-u na 6295 stranica, odnosno da je prosječna dužina članka u analiziranom razdoblju iznosila 10,82 stranice po pojedinom radu. Analizom dobivenih rezultata najveće je odstupanje u godištu 17 gdje je ukupno 671 stranica i godištu 5 gdje su svega 162 stranice (slika 1). Cjelovitim pregledom utvrdilo se da je u godištu 17 objavljeno ukupno 49 radova, dok je u godištu 5 objavljeno svega 15 radova, te je zbog toga značajna razlika u broju stranica između godišta. Rad s najmanjim brojem stranica publiciran je u godištu 1 i zauzima svega tri stranice (stručni rad), dok radu iz godišta 5 pripada 39 stranica.

\footnotetext{
15 Pehar, Franjo. Komunikacijska uloga časopisa u polju informacijskih znanosti : bibliometrijska analiza Vjesnika bibliotekara Hrvatske i Informatologije : disertacija. Zagreb: Filozofski fakultet, 2010. Str. 105.

16 Radovi su kategorizirani sukladno kategorizaciji u časopisu MC.
} 


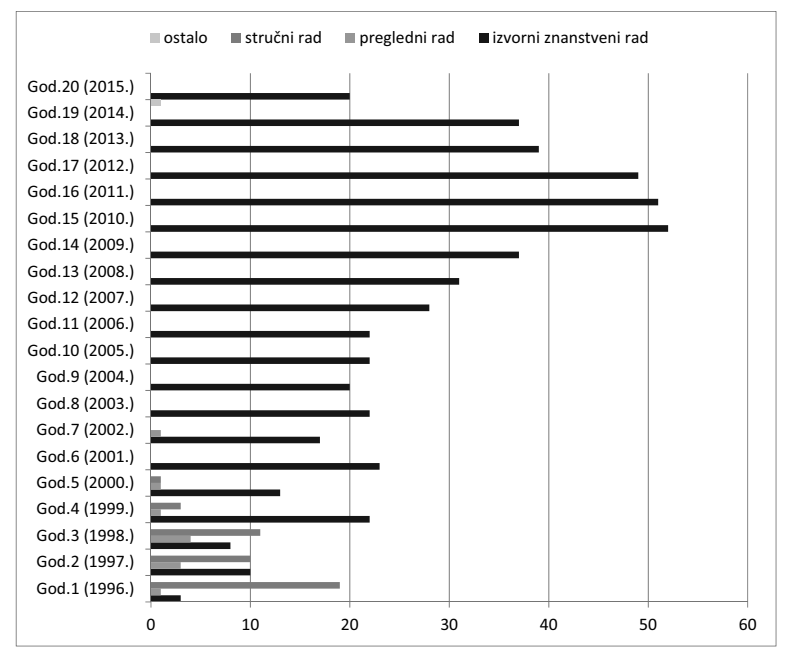

Slika 1. Broj objavljenih radova i broj stranica u pojedinom godištu MC-a

Analizom dobivenih rezultata (slika 2) utvrđeno je da su publicirana ukupno 582 rada. U godištu 15 (2010.) publiciran je najveći broj radova, 52 izvorna znanstvena rada, dok je u godištima 9 (2004.) i 20 (2015.) publicirano po 20 izvornih znanstvenih radova. Također je vidljivo da se najveći broj stručnih radova publicirao u prvim godinama izlaženja te da se kroz godine njihov broj smanjuje, a od godišta 6 (2001.) nije publiciran nijedan stručni rad; također se od istog godišta u časopisu objavljuju isključivo izvorni znanstveni i pregledni radovi na engleskom jeziku.

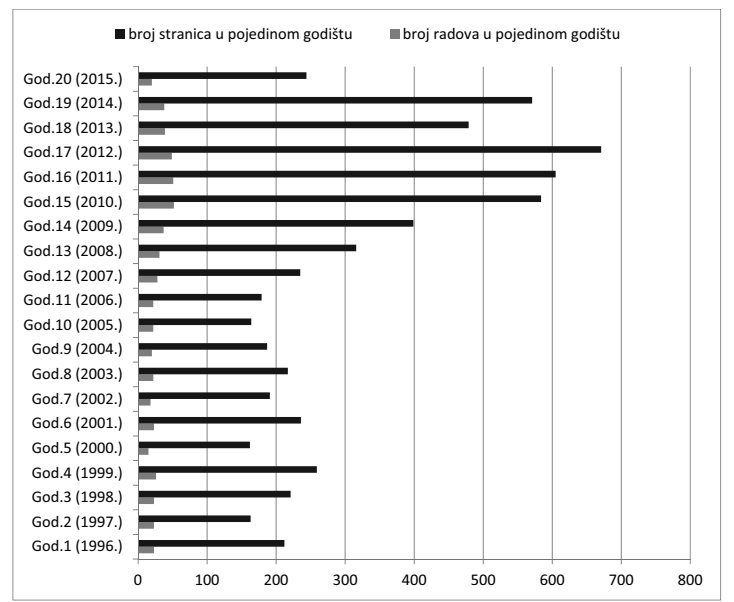

Slika 2. Vrste objavljenih radova u časopisu MC po godištima 
Iz rezultata analize strukture radova (slika 3) objavljenih u MC-u vidljivo je da je od ukupno 582 rada njih 526 (90,38 \%) kategorizirano kao izvorni znanstveni rad, 44 rada $(7,56 \%)$ kategorizirani su kao stručni radovi, preglednim radom kategorizirano je 11 radova (1,89\%), a u kategoriju ostali radovi svrstan je samo jedan rad, i to kao korekcija rada $(0,17 \%)$. Većina radova objavljenih u MC-u napisana je na engleskom jeziku (98.97\%), dok je na hrvatskom jeziku objavljeno svega 6 stručnih radova iz prvog godišta $(1,03 \%)$.

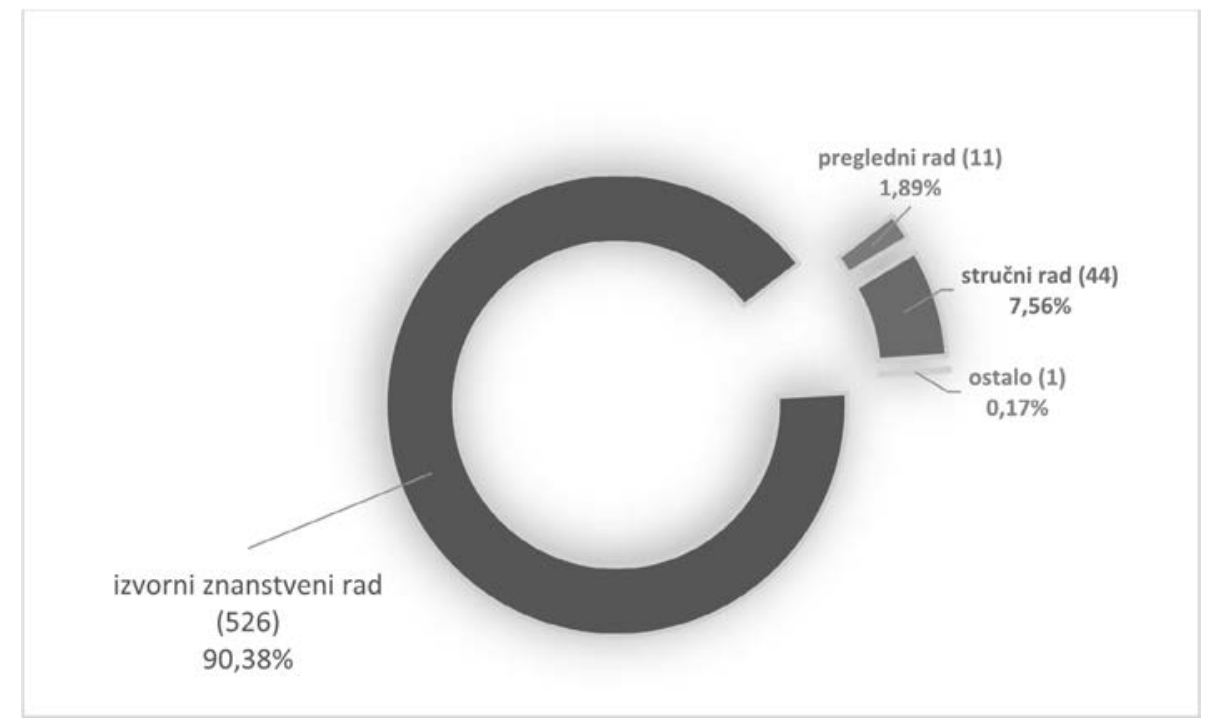

Slika 3. Struktura radova objavljenih u MC-u prema vrsti rada

\subsection{Autori zastupljeni u časopisu MC}

Do danas je 659 autora (broj dobiven zbrajanjem autora po svakom radu) publiciralo svoje radove u časopisu MC. Analiza autora napravljena je prema državi iz koje autor dolazi (slika 4), ali je grafički prikazana i po kontinentima radi bolje preglednosti (slika 5). 


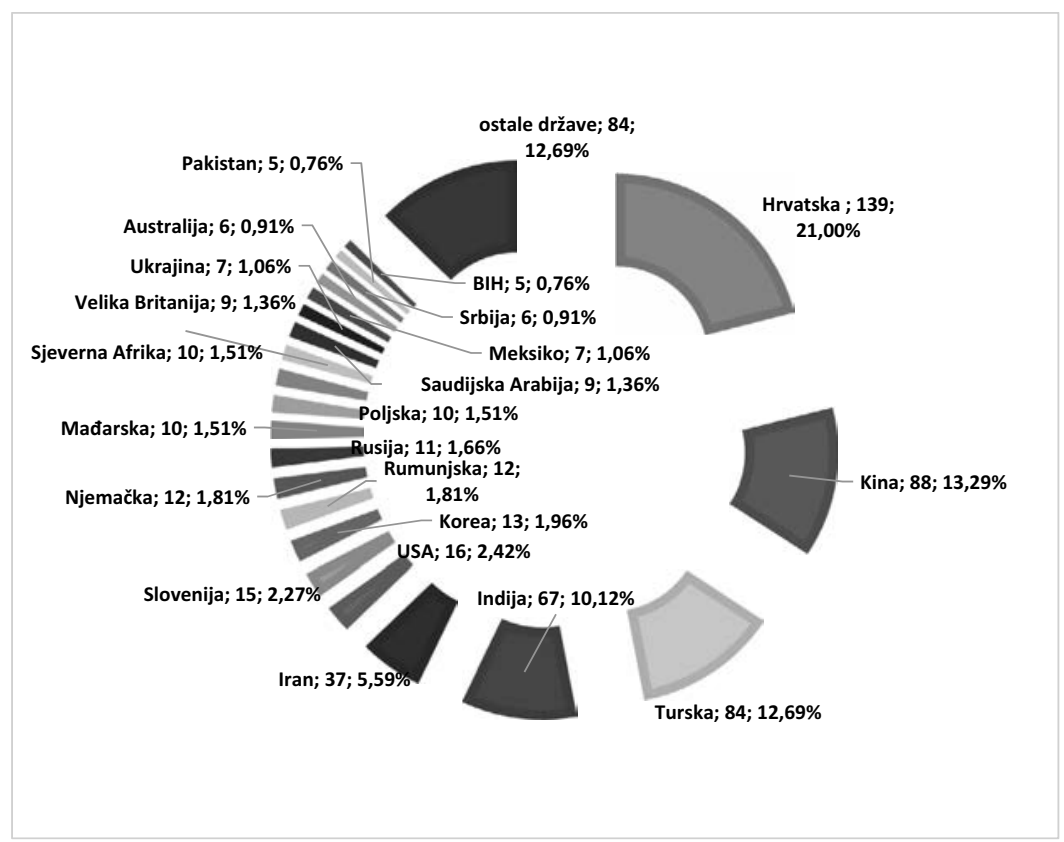

Slika 4. Zastupljenost autora po državama

Na slici 4 prikazane su države iz kojih dolazi pet ili više autora, dok su države s manjim brojem autora svrstane u kategoriju „ostale države“. Analizom rezultata utvrdilo se da najveći broj autora dolazi iz Hrvatske (139), Kine (88), Turske (84), Indije (67), Irana (37), SAD-a (16), Slovenije (15) i Južne Koreje (13); Rumunjska i Njemačka imaju po 12 autora koji su publicirali svoje radove u MC-u, a po deset je autora iz Mađarske, Poljske i Sjeverne Afrike, dok po devet autora dolazi iz Velike Britanije i Saudijske Arabije. Iz Ukrajine i Meksika dolazi po sedam autora, iz Australije i Srbije po šest, dok je iz Pakistana i Bosne i Hercegovine po pet autora. Portugal, Makedonija, Brazil, Vijetnam, Japan i Kosovo zastupljeni su s po četiri autora. Po tri autora dolaze iz Kolumbije, Koreje, Alžira, Obale Bjelokosti, Malezije, Tunisa, Italije i Francuske, dok su svega 2 autora iz Izraela. Utvrđeno je da inozemni autori sve više publiciraju svoje radove u MC-u nakon što je časopis indeksiran u bazama podataka WoSCC i Scopus. Nakon analize rezultata zastupljenih autora po kontinentima vidljivo je da njih 224 dolazi s područja Azije, 220 iz Europe (bez Hrvatske), 20 iz Afrike, 16 autora dolazi iz Sjeverne Amerike, 14 iz Južne Amerike, a 6 autora iz Australije (slika 5). Analizom se utvrdilo da je povećan broj publiciranih radova inozemnih autora nakon što je $\mathrm{MC}$ indeksiran u relevantnim bazama podataka. 


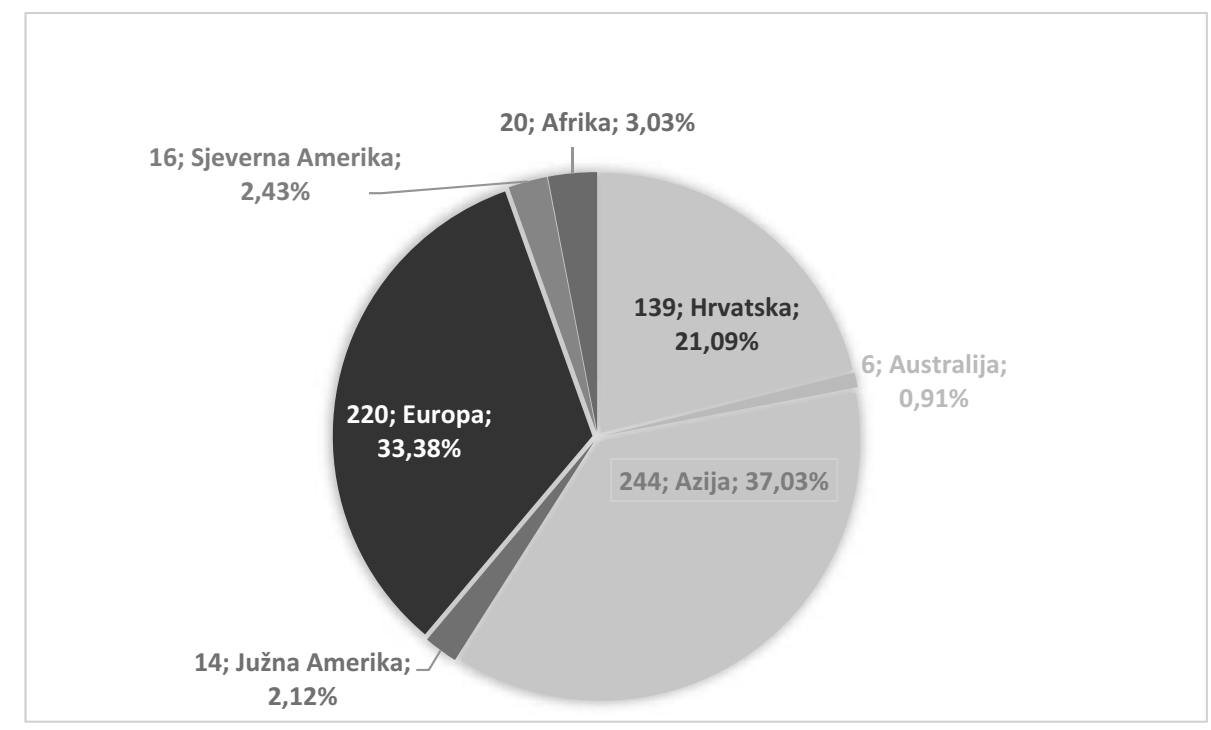

Slika 5. Zastupljenost autora po kontinentima i hrvatski autori

Utvrđeno je da je po autoru publicirano 0,88 radova. Uočeno je i da je svega jedan rad s pet autora iz MC 2014. (vol. 19, br.1), jedanaest radova ima četiri autora, 83 rada napisala su zajedno tri autora, dok prevladavaju jednoautorski (297 radova) i dvoautorski radovi (190) (slika 6). Hrvatski autor koji ima najveći broj radova publiciranih u MC-u je Volenec, V., koji ukupno ima 19 izvornih znanstvenih radova, a od toga šest jednoautorskih, šest dvoautorskih, pet troautorskih i dva rada u kojima su četiri autora, a koji su publicirani u razdoblju od 1997. (vol. 2) do 2014. (vol. 19), dok od inozemnih autora najveći broj radova ima autor Späth, H. iz Njemačke (ukupno 14 izvornih znanstvenih radova, 13 jednoautorskih i jedan dvoautroski rad) publiciranih u razdoblju od 1998. (vol. 3) do 2013. (vol. 18). Važno je naglasiti da je u prvim godinama izlaženja časopisa njegova vidljivost među stranim autorima ostvarena kroz razmjenu časopisa MC. 


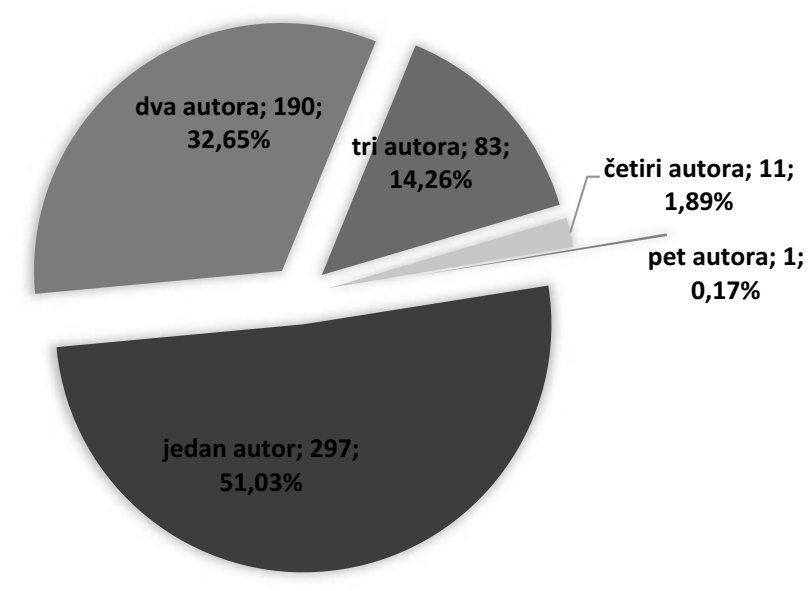

Slika 6. Broj autora po objavljenom radu

\subsection{Broj referenci zastupljenih u radovima objavljenim u $M C-u$}

Danas se oprema tekstova referencijama smatra ,kulturnom tekovinom“ znanstvenoga komuniciranja, pa ih stoga mnoga uredništva znanstveno-stručnih časopisa drže za jedan od preduvjeta prihvaćanja rukopisa. ${ }^{17}$ Analiza 582 rada publicirana u MC-u u dvadesetogodišnjem razdoblju pokazala je da se većina autora koristila citiranjem publikacija. Svega osam radova nema reference. Pregledom istih utvrdilo se da su to stručni radovi, odnosno objavljena predavanja sa skupa u prva tri godišta MC-a. Utvrdilo se da su ukupno 8294 reference korištene u radovima publiciranim u MC-u, od čega se 5939 (70,69 \%) referenci odnosi na inozemne časopise, 2119 (25,22 \%) odnosi se na knjige, a $236(2,81 \%)$ odnosi se na hrvatske časopise (slika 7).

Pehar, Franjo. Komunikacijska uloga časopisa u polju informacijskih znanosti : bibliometrijska analiza Vjesnika bibliotekara Hrvatske i Informatologije : disertacija. Nav. dj., str. 212. 


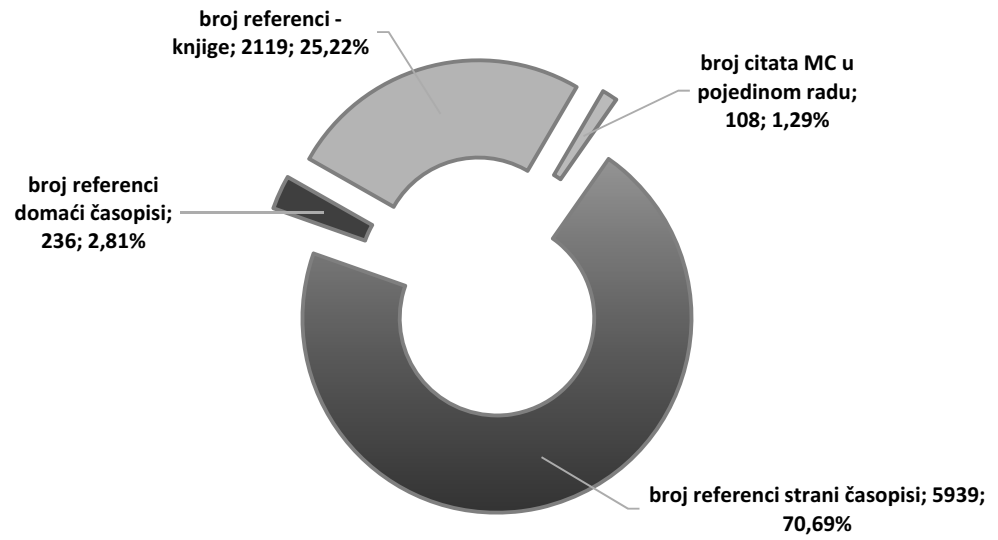

Slika 7. Ukupan broj referenci svih godišta MC-a

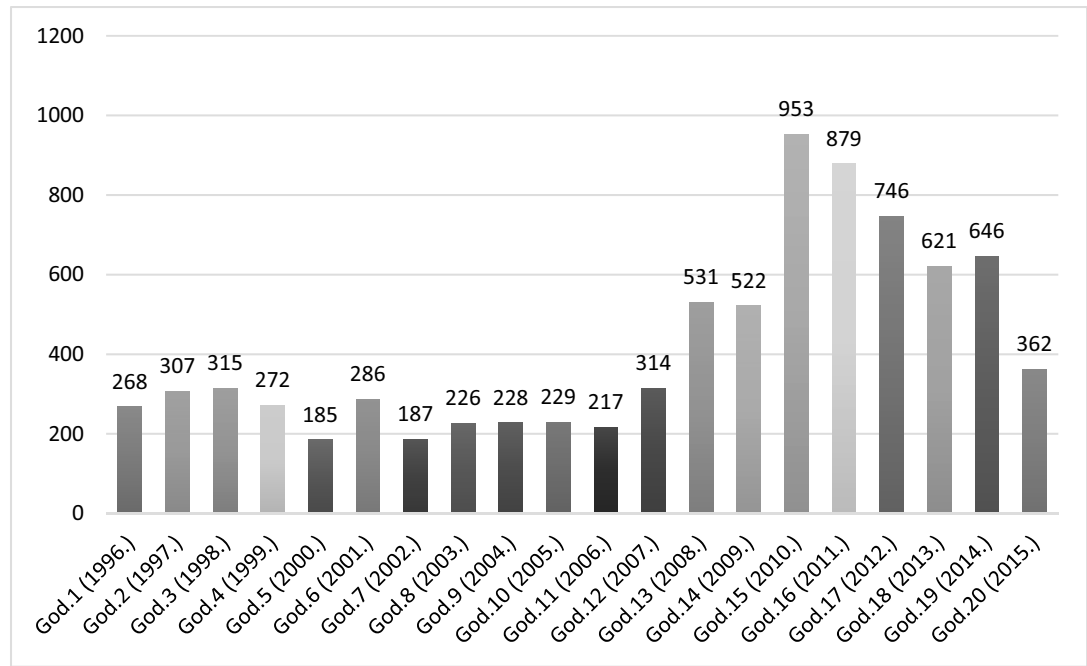

Slika 8. Ukupan broj referenci po godištima MC-a

Analizom se utvrdilo da se među referencama korištenim u publiciranim radovima u MC-u nalaze i radovi iz MC-a, i to 108 (1,29 \%) radova. Prva referenca iz MC-a nalazi se u drugom sveščiću godišta 1 , dok je najveći broj referenci iz MC-a u godištu 18 (2013.) - ukupno 14 referenci. Analizom je utvrđeno da je od tog broja svega dvadeset pet samocitata. 


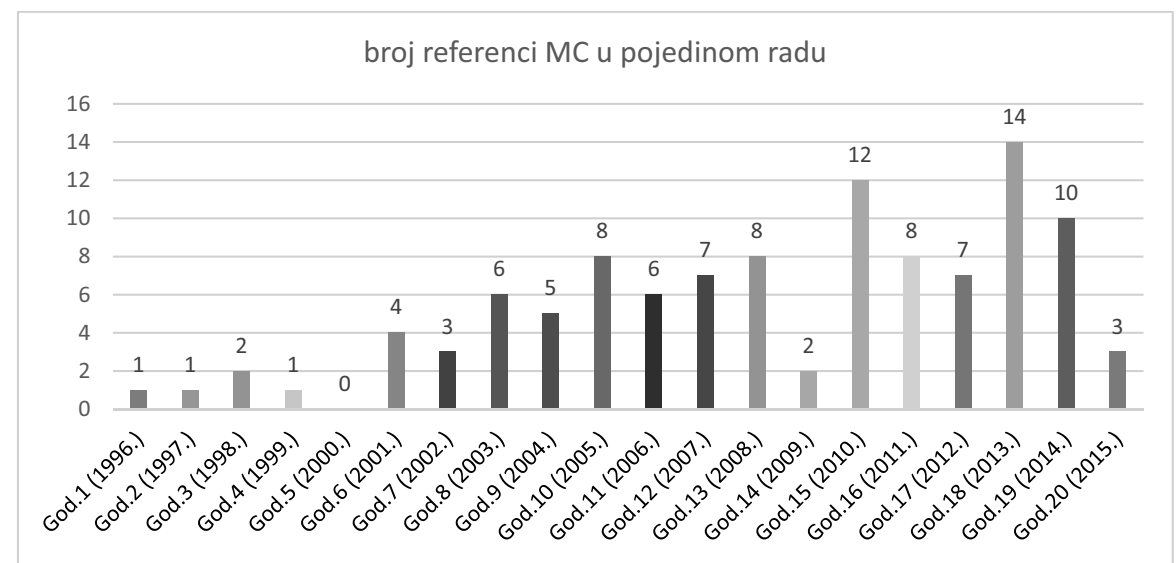

Slika 9. Broj radova po godištima u kojima su kao reference navedeni drugi radovi zastupljeni u MC-u

\subsection{Indeksiranost i citiranost radova objavljenih u MC-u}

\section{UWoSCC- $u$}

Analizom dobivenih rezultata o broju i citiranosti radova indeksiranih u WoSCC-u od 2008. do 2015. godine utvrđeno je da je indeksirano 318 radova, a koji su citirani 427 puta. Analizira li se citiranost po godinama (slika 10), vidi se stalni porast citiranosti indeksiranih radova, od 2008., god. 13, kada je MC ušao u WoSCC s 31 radom i samo jednim citatom, pa do 2015., god. 20, kada je samo u toj godini citiran 111 puta.

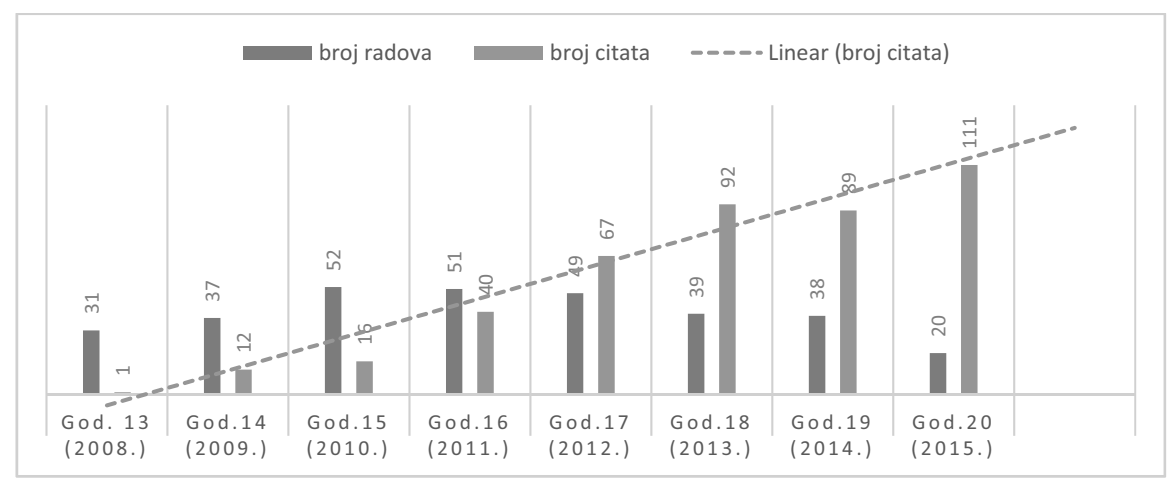

Slika 10. Indeksirani i citirani radovi u WoSCC-u po godinama 
Analizom citiranosti po radu indeksiranom u WoSCC-u (slika 11) utvrđeno je da su citirana 144 rada koja su publicirana u MC-u od 2008. do 2015. godine. Uočava se da je 61 rad citiran jednom, 28 radova ima po dva citata, a osam radova citirano je više od 10 puta. Analizom citata utvrđeno je da je rad autora Indulal, G. ${ }^{18}$ i Gutman, I. iz 2008. ${ }^{19}$ najcitiraniji indeksirani rad (26 citata), dok je rad autora Imdad, M. i Ali, J. iz 2006. godine najcitiraniji neindekisrani rad (10 citata) u bazi podataka WoSCC. H-indeks MC-a je 8, što znači da je od ukupno 318 indeksiranih radova njih 8 citirano više od 8 puta.

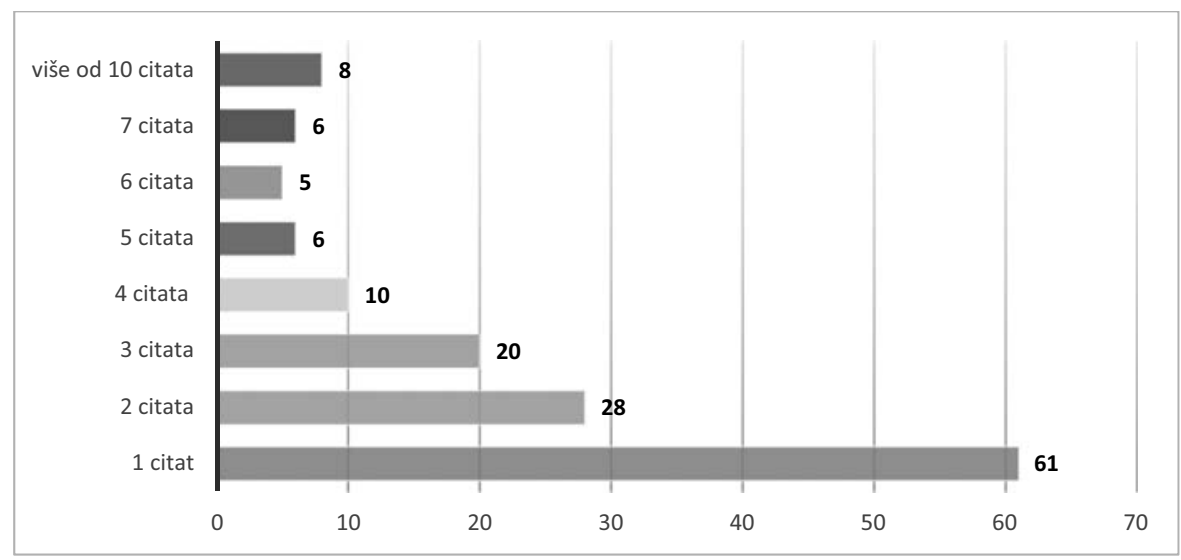

Slika 11. Broj citata po radu indeksiranom u WoSCC-u

\section{U Scopusu}

Analizom dobivenih rezultata o broju indeksiranih radova i citiranosti radova indeksiranih u Scopusu po godinama (slika 12) vidljiv je značajan stalni porast citiranosti indeksiranih radova. Tako je od 2008. godine, god. 13, kada je MC ušao u Scopus s 31 radom i samo 1 citatom (rad autora Červar, B. i Uglešić, N. iz br. 1 (2008.) jest prvi indeksirani rad koji je citiran) broj citata u 2015. porastao na 131, tako da je u prosincu 2015. godine od ukupnog broja indeksiranih radova (318) njih 169 citirano 529 puta. Analizom citata utvrđeno je da je rad autora Indulal, G. i Gutman, I. iz 2008. najcitiraniji indeksirani rad (29 citata) dok je rad autora Imdad, M. i Ali, J. iz 2006. godine najcitiraniji neindekisrani rad (26 citata) u bazi podataka Scopus. H-indeks MC-a u bazi podataka Scopus je 9, što znači da je 9 radova citirano devet i više puta.

18 Autoru je u bazi WoSCC krivo napisano ime i prezime - autor se zove Gopalapillai Indulal.

19 Indulal, Gopalapillai; Ivan Gutman. On the distance spectra of some graphs. // Mathematical Communications 13, 1(2008), 123-131. [citirano 2016-07-14]. Dostupno na http://hrcak.srce.hr/ index.php?show=clanak\&id_clanak_jezik=37132. 


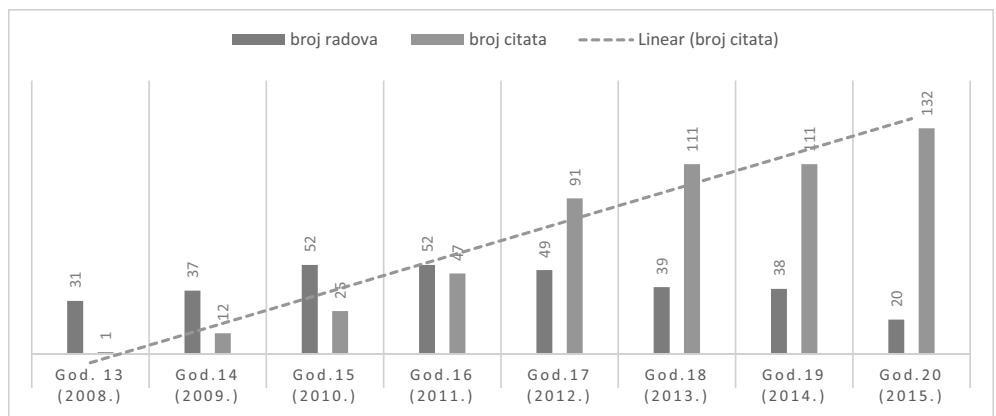

Slika 12. Indeksirani i citirani radovi u Scopusu po godinama

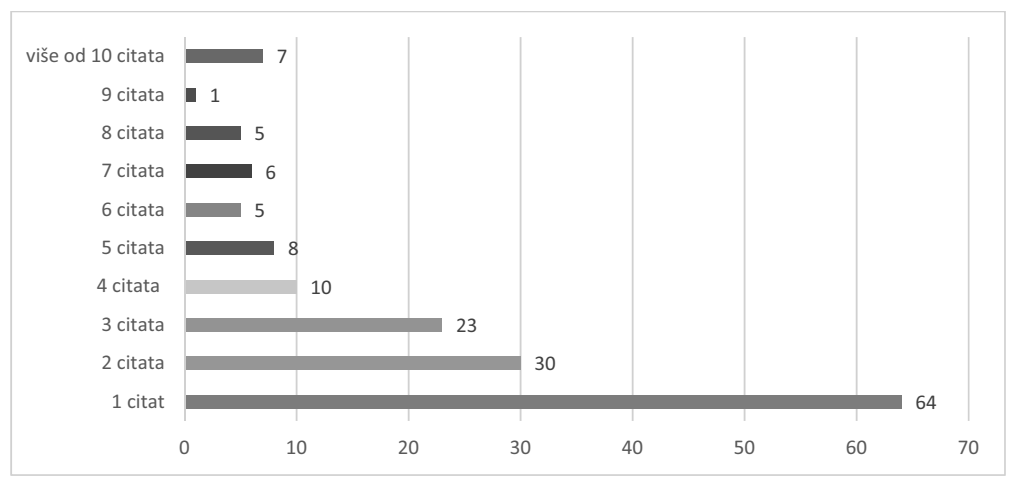

Slika 13. Broj citata po radu indeksiranom u Scopusu

\section{U WoSCC-u i Scopusu}

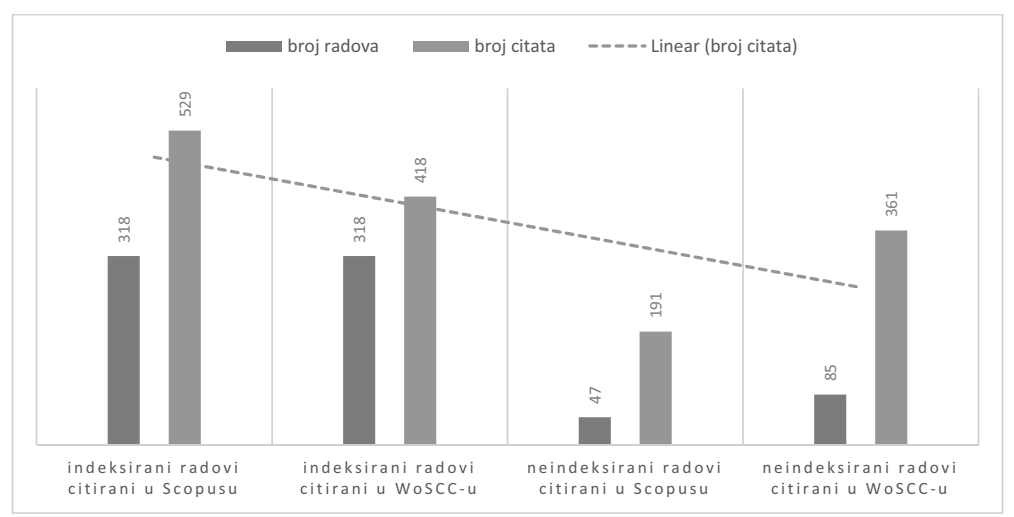

Slika 14. Broj i citiranost indeksiranih i neindeksiranih radova u WoSCC-u i Scopusu 
Analizom ukupno dobivenih rezultata o broju i citiranosti radova indeksiranih u bazama Scopus i WoSCC (slika 13) vidi se da je u obje baze indeksirano 318 radova (od 2008., vol. 13 do 2015., vol. 20) te da je ukupna citiranost indeksiranih radova različita za 111 citata, što se može objasniti činjenicom da baza Scopus indeksira više časopisa u kojima su publicirali autori koji su citirali radove publicirane u MC-u. Analizom dobivenih podataka utvrdilo se da je u bazi podataka WoSCC više neindeksiranih radova (85) objavljenih u MC-u, a koje su autori citirali (ukupno 361 citat), nego u bazi Scopus u kojoj je 47 neindeksiranih radova citirano 191 put. (slika 13).

Analizirajući rezultate citiranosti utvrdilo se da je indeksirani rad autora Indulal, G. i Gutman, I. iz 2008. najcitiraniji indeksirani rad u obje baze te da razlika od 3 citata ide u korist baze podataka Scopus. Također se utvrdilo da je najcitiraniji neindeksirani publicirani rad autora Imdad, M. i Ali, J. iz 2006. godine, ali razlika u broju citata na ovom je radu još vidljivija i iznosi 16 citata.

$\mathrm{U}$ bazi WoSCC analizom rezultata utvrđeno je svega dvadeset pet samocitata u ukupnom broju od 418 citata. To može biti jedan od važnih čimbenika za procjenu kvalitete radova publiciranih u MC-u. Isto tako, ne smije se zanemariti ni činjenica da je MC časopis iz područja matematike, a nije isto kojem području pripada citirani rad, kao što kaže i Stojanovski u svom radu iz 2010. godine: matematičar čiji je rad u 11 godina prikupio 45 citata pripadat će u $1 \%$ najcitiranijih autora u području, dok će molekularni biolog čiji rad u 11 godina prikupi 100 citata pripadati „samo“ u gornjih $10 \%$ najcitiranijih autora. ${ }^{20}$ Također, I. Podlubny navodi da je jednom citatu iz matematike ekvivaletno 15 citata iz kemije, odnosno 19 citata iz fizike, a 78 citata iz kliničke medicine. ${ }^{21}$

\section{5. Časopis MC u izvješćima o citiranosti časopisa JCR (Journal Citation Report) i SCImago Journal \& Country Rank}

Prve izračune u JCR-u časopis MC ima u 2010. godini, odnosno dvije godine nakon indeksiranja u bazi podataka WoSCC. U 2010. godini čimbenik odjeka (engl. impact factor - IF) bio mu je 0,176 jer je zbroj citiranih indeksiranih radova publiciranih u MC-u 2008. i 2009. bio 12, a ukupan broj publiciranih radova u te dvije godine bio je 68 . Kada se broj citata podijeli s brojem publiciranih radova, dobije se čimbenik odjeka $(12: 68=0,176)$. S obzirom na to da je IF MC-a u 2010. godini zauzeo 228. mjesto od ukupno 236 časopisa koji se nalaze u kategoriji Applied Mathematics, najbolje je bio rangiran u 2012. godini, kada je zauzeo 203. mjesto s IF 0,447 (tablica 1). Kroz proteklih pet godina, otkako MC ima izračun IF u JCR-u u kategoriji Applied Mathematics, nalazi se u četvrtom kvartilu. Ako usporedimo kategoriju Mathematics, vidi se da je MC također bio najbolje ran-

\footnotetext{
20 Stojanovski, Jadranka. Metrika znanstvene publicistike - istina, mitovi i zablude. // Kemija u industriji 59, 4(2010), str. 183.

21 Podlubny, Igor. Comparison of scientific impact expressed by the number of citations in different fields of science. // Scientometrics 64, 1(2005), str.97.
} 
giran u 2012. godini, kada je imao IF 0,447 i zauzeo 203. mjesto od ukupno 296 časopisa na listi te kategorije te je ušao u treći kvartil.

Tablica 1. Časopis MC u izvješćima o citiranosti časopisa JCR (Journal Citation Report)

\begin{tabular}{|l|c|c|c|c|c|}
\hline godina & $\begin{array}{c}\text { IF kroz } \\
\text { godine } \\
\text { JCR }\end{array}$ & $\begin{array}{c}\text { Mjesto } \\
\text { unutar } \\
\text { skupine }\end{array}$ & $\begin{array}{c}\text { kvartili JCR-a } \\
\text { (kategorija: } \\
\text { Mathematics, Applied) }\end{array}$ & $\begin{array}{c}\text { Mjesto } \\
\text { unutar } \\
\text { skupine }\end{array}$ & $\begin{array}{c}\text { kvartili JCR-a } \\
\text { (kategorija: } \\
\text { Mathematics) }\end{array}$ \\
\hline 2010. & 0.176 & $228 / 236$ & Q4 & $287 / 312$ & Q4 \\
\hline 2011. & 0.258 & $229 / 245$ & Q4 & $271 / 302$ & Q4 \\
\hline 2012. & 0.447 & $203 / 247$ & Q4 & $203 / 296$ & Q3 \\
\hline 2013. & 0.300 & $233 / 251$ & Q4 & $267 / 289$ & Q4 \\
\hline 2014. & 0.284 & $249 / 257$ & Q4 & $267 / 279$ & Q4 \\
\hline
\end{tabular}

U SCImago Journal \& Country Ranku časopis MC smješten je u područje matematike, ali u četiri različite kategorije: Mathematics Applied, Algebra and Number Theory, Analysis i Geometry and Topology. Od 2010. do 2014. godine u kategorijama Algebra and Number Theory, Analysis i Geometry and Topology MC se nalazi u četvrtim kvartilima, dok se od 2015. godine nalazi u trećem kvartilu. U kategoriji Mathematics Applied 2010. i 2011. bio je u četvrom kvartilu, a od 2012. godine nalazi se u trećem kvartilu. Uočava se da se citiranost radova sustavno povećava otkako je MC indeksiran u bazama podataka.

Tablica 2. Časopis MC u izvješćima o citiranosti časopisa SCImago Journal \& Country Rank

\begin{tabular}{|c|c|c|c|c|c|c|c|}
\hline godina & $\begin{array}{l}\text { IF kroz } \\
\text { godine } \\
\text { SCIMago }\end{array}$ & $\begin{array}{c}\text { Mathematics, } \\
\text { Applied } \\
\text { (rang- } \\
\text { mjesto) }\end{array}$ & $\begin{array}{l}\text { kvartili } \\
\text { SCIMago }\end{array}$ & $\begin{array}{c}\text { Algebra } \\
\text { and } \\
\text { Number } \\
\text { Theory } \\
\text { (rang- } \\
\text { mjesto) }\end{array}$ & $\begin{array}{c}\text { Analysis } \\
\text { (rang- } \\
\text { mjesto) }\end{array}$ & $\begin{array}{c}\text { Geometry } \\
\text { and } \\
\text { Topology } \\
\text { (rang- } \\
\text { mjesto) }\end{array}$ & $\begin{array}{c}\text { kvartili } \\
\text { SCIMago } \\
\text { (kategorije: } \\
\text { Algebra and } \\
\text { Number } \\
\text { Theory, } \\
\text { Analysis i } \\
\text { Geometry } \\
\text { and Topology }\end{array}$ \\
\hline 2010. & 0,184 & $326 / 371$ & Q4 & $63 / 64$ & $94 / 101$ & $55 / 58$ & Q4 \\
\hline 2011. & 0,292 & $292 / 383$ & Q4 & $60 / 68$ & $89 / 110$ & $52 / 61$ & Q4 \\
\hline 2012. & 0,304 & $293 / 403$ & Q3 & $59 / 73$ & $93 / 115$ & $53 / 64$ & Q4 \\
\hline 2013. & 0,368 & $284 / 405$ & Q3 & $59 / 76$ & $94 / 116$ & $50 / 65$ & Q4 \\
\hline 2014. & 0,302 & $303 / 403$ & Q3 & $61 / 75$ & $89 / 114$ & $52 / 62$ & Q4 \\
\hline 2015. & 0,382 & $278 / 461$ & Q3 & $58 / 78$ & $87 / 118$ & $50 / 71$ & Q3 \\
\hline
\end{tabular}


Čimbenik odjeka nekoga časopisa treba uzeti s rezervom jer pri izračunu nisu uzeti u obzir citirani radovi koji su publicirani prije nego što je časopis indeksiran u nekoj od baza podataka.

\section{Zaključak}

Znanstveni časopisi primarno su sredstvo priopćavanja u velikom broju znanstvenih disciplina. Svim sudionicima u postupku stvaranja i prijenosa znanstvenih informacija - znanstvenici, izdavači, knjižnice, sveučilišta, tijela koja financiraju znanstvena istraživanja - vrednovanje znanstvenih časopisa važno je pitanje, pri čemu se primjenjuju različiti kriteriji. Bibliometrijski pokazatelji mogu biti pouzdano mjerilo zastupljenosti i utjecaja znanstvenoga časopisa u zajednici u kojoj djeluje i kojoj se obraća.

Časopis Mathematical Communications (MC) pokrenut je 1996. godine. Pokrenuli su ga znanstvenici sa Zavoda za primijenjenu matematiku okupljeni oko Udruge matematičara Osijek. Tijekom dvadeset godina izlaženja kvaliteta časopisa rasla je kao i njegova vidljivost unutar znanstvene zajednice, kako domaće tako i inozemne. Od 1998. godine njegovo izdavanje sufinancira Ministarstvo znanosti, obrazovanja i sporta Republike Hrvatske. Recenzije su međunarodne (najmanje dvije), a kontakti s autorima i recenzentima odvijaju se putem interneta. Od 2008. godine časopis je indeksiran u bazama podataka WosCC i Scopus. Od 2013. publiciranje se obavlja preko Open Journal Systema (OJS - an electronic journal management and publishing system). Od 1997. godine objavljuju se radovi isključivo na engleskome jeziku.

Cilj ovoga istraživanja bio je utvrditi je li vidljivost časopisa porasla otkako je časopis indeksiran $\mathrm{u}$, trenutno za hrvatsku akademsku zajednicu najznačajnijim, bazama podataka Web of Science Core Collection i Scopus. U radu je obrađeno 20 godišta, ukupno 41 sveščić časopisa. Parametri za istraživanje prikupljeni su iz časopisa te iz baza Web of Science Core Collection i Scopus. U obzir su uzeti sljedeći parametri: broj objavljenih radova i broj stranica, vrste objavljenih radova, država i kontinent odakle dolaze autori, broj autora po jednom radu, broj i vrsta izvora zastupljenih referenci, radovi u kojima su kao reference navedeni drugi radovi zastupljeni u MC-u, broj indeksiranih i citiranih radova u bazama WoSCC i Scopus, citiranost neindeksiranih radova u bazama WoSCC i Scopus, IF, kvartil i poredak unutar kategorije u izvješćima o citiranosti časopisa JCR (Journal Citation Report) i SCImago Journal \& Country Rank.

Rezultati istraživanja pokazali su da je, nakon što je časopis indeksiran u bazama podataka WoSCC i Scopus, broj radova u pojedinom godištu, a sukladno tomu i broj stranica, značajno porastao, da se u njemu objavljuju gotovo isključivo izvorni znanstveni radovi, da je broj inozemnih autora povećan, da je povećan broj referenci na koje autori upućuju, a koje se u značajnom broju odnose na strane ča- 
sopise i knjige, te da broj referenci koje se odnose na radove objavljene u časopisu $\mathrm{MC}$ nije velik. Osim toga, značajno je porasla citiranost radova u bazama WoSCC i Scopus, a primjećuju se i pozitivni pomaci pri rangiranju časopisa u izvješćima o citiranosti časopisa JCR (Journal Citation Report) i SCImago Journal \& Country Rank.

Pritom valja naglasiti da za kvalitetu pojedinoga rada nije toliko važno je li rad indeksiran u prestižnim bazama podataka koliko je važno može li mu se pristupiti (potvrda otvorenog pristupa) te na kojem je jeziku rad napisan, što potvrđuje brojka od 85 radova koji nisu indeksirani u bazi WoSCC, a citirani su 361 put u časopisima koji su indeksirani u njoj. Jedan od bitnih pokazatelja kvalitete časopisa jest i samocitiranje, a analizom u bazi WoSCC vidi se da je svega 5,98 \% samocitata u ukupnom broju citata indeksiranih radova.

Danas je časopis MC jedini znanstveni časopis iz područja prirodnih znanosti čiji je izdavač jedna od sastavnica Sveučilišta Josipa Jurja Strossmayera u Osijeku. Sustavnim radom i uređivačkom politikom u publiciranju radova uredničkog odbora MC je postao prepoznatljiv i prihvaćen časopis u području matematike.

\section{LITERATURA}

Borić, Vesna; Mihovil Strujić. Bibliometrijska analiza Acta stomatologica Croatica za razdoblje od godine 1987. do 2006. // Acta stomatologica Croatica 40, 4(2006), 336346.

Bornmann, Lutz; Rüdiger Mutz; Christoph Neuhaus; Hans-Dieter Daniel. Citation counts for research evaluation: standards of good practice for analyzing bibliomteric data and presenting and interpreting results. // Ethics in Science and Enviromental Politcs 8(2008), 93-102.

Hrvatska enciklopedija - časopis [citirano: 2017-04-24] Dostupno na http://www.enciklopedija.hr/Natuknica.aspx?ID=13196

Jokić, Maja. Bibliometrijski aspekti vrednovanja znanstvenog rada. Zagreb: Sveučilišna knjižara, 2005.

Keener, Molly; Joy Kirchner; Sarah Shreeves; Lee Van Orsdel. 10 things you should know about scholarly communication. // ACRL 14th National Conference 2009 "Scholarly Communication 101" workshop; last updated May 10, 2013. str. 1. [citirano: 2017-04-25] Dostupno na http://www.ala.org/acrl/sites/ala.org.acrl/files/content/ issues/scholcomm/docs/ten_things_you_should_know.pdf

Macan, Bojan; Jadranka Stojanovski. Analiza novčane potpore Ministarstva znanosti, obrazovanja i športa hrvatskim znanstvenim časopisima. // Kemija u industriji 57, 
3(2008), 115-122. Dostupno i na http://hrcak.srce.hr/index.php?show=clanak\&id_ clanak_jezik=32964 [citirano: 2017-04-25].

Macan, Bojan. Kriteriji za evaluaciju znanstvenih časopisa -prednosti i mane. // 9. Seminar knjižnica u sustavu znanosti i visoke naobrazbe "Knjižnica uzvraća udarac: reorganizacija imperija". Zagreb, 13. i 14. studenoga 2009. [citirano: 2017-04-25] Dostupno na https://bib.irb.hr/datoteka/437794.Macan_B_Evaluacija_casopisa. pdf

Pehar, Franjo. Komunikacijska uloga časopisa u polju informacijskih znanosti : bibliometrijska analiza Vjesnika bibliotekara Hrvatske i Informatologije : disertacija. Zagreb: Filozofski fakultet, 2010.

Pehar, Franjo. Od statističke bibliografije do bibliometrije: povijest razvoja kvantitativnog pristupa istraživanju pisane riječi. // Libellarium 3, 1(2010), 1-28. [citirano: 2017-04-25] Dostupno na http://hrcak.srce.hr/index.php?show=clanak\&id_clanak_ jezik $=110191$

Podlubny, Igor. Comparison of scientific impact expressed by the number of citations in different fields of science. // Scientometrics 64, 1(2005), 95-99. Dostupno i na https:// link.springer.com/article/10.1007/s11192-005-0240-0 [citirano: 2017-04-25].

Portal elektroničkih izvora za hrvatsku akademsku i znanstvenu zajednicu - Journal citation Reports. [citirano: 2017-04-25] Dostupno na http://baze.nsk.hr/baza/journal-citation-reports/

Stojanovski, Jadranka. Metrika znanstvene publicistike - istina, mitovi i zablude. // Kemija u industriji 59, 4(2010), 179-186. Dostupno i na http://hrcak.srce.hr/index. php?show=clanak\&id_clanak_jezik=77493 [citirano: 2017-04-25].

Šercar, Tvrtko. Časopis kao sredstvo institucionalizacije znanosti. // Acta stomatologica Croatica 21, 4(1987), 319-324. Dostupno i na http://hrcak.srce.hr/105141 [citirano: 2017-04-25].

Šušak Lukačević, Mirna; Sanda Hasenay; Ivana Šuvak-Pirić. Izgradnja zbirke periodike razmjenom za časopis Mathematical Communications u knjižnici Odjela za matematiku Sveučilišta u Osijeku. // Knjižničarstvo 17, 2(2013), 57-74. Dostupno i na http://www.knjiznicarstvo.com.hr/wp-content/uploads/2014/05/227_Susak-Lukacevic_Hasenay_Suvak-Piric_2013_2.pdf [citirano: 2017-04-25]. 